\title{
First discovery of nautilids from the Albian- Cenomanian succession of the Koppeh Dagh Basin, NE Iran
}

\author{
Javad Sharifi ${ }^{*}$, Amane Tajika ${ }^{2,3}$, Alireza Mohammadabadi ${ }^{1}$ and Mohammad Hossein Tabari Abkuh ${ }^{1}$
}

\begin{abstract}
The Aitamir Formation, situated in the Koppeh Dagh Basin in the northeast of Iran, is known for its well-exposed Albian-to-Cenomanian succession. Although geologists previously documented a number of macro- and microfossils, no nautilids had been discovered until now to our knowledge. Here, we present lower Albian and middle Cenomanian nautilids from the Koppeh Dagh Basin for the first time. This discovery is also the first record of Cretaceous nautilids from Iran. We identified the specimens as Eutrephoceras clementianum (d'Orbigny 1840), E. sublaevigatum (d'Orbigny 1850), E. bouchardianum (d'Orbigny 1840) and Eutrephoceras sp. These specimens occur in horizons situated between several ammonite-bearing levels, which allowed us to more precisely constrain age estimates for the recovered nautilid specimens. E. clementianum could not be dated precisely but likely comes from between late Aptian ammonite index Hypacanthoplites uhligi and middle Albian Hoplites (Hoplites) baylei. E. sublaevigatum occurs just above the late Albian ammonites Mariella bergeri and Semenoviceras michalskii and below the Mantelliceras mantelli Zone. At the upper part of the section, E. bouchardianum and Eutrephoceras sp. were collected from lower Albian beds, which correspond to the Mantelliceras mantelli and Mantelliceras dixonii zones. These new findings contribute to our knowledge of the geographical distribution and stratigraphic range of Albian-Cenomanian nautilid species.
\end{abstract}

Keywords: Nautilids, Eutrephoceras, Cretaceous, Koppeh Dagh, Aitamir

\section{Introduction}

The Nautiloidea (de Blainville, 1825) is a group of ectocochleate cephalopods that has a long geological record, originating in the late Cambrian (Kröger et al., 2011). Although nautilid fossils have been reported worldwide for some hundred years, a comprehensive study of the mid-Cretaceous nautilids is critically lacking. The genus Eutrephoceras (Hyatt, 1894) is one of the most common nautilid taxa in the Cretaceous and an interesting group to study because they survived the K/Pg mass extinction event (e.g., Landman et al., 2014). However,

\footnotetext{
Editorial handling: Christian Klug.

*Correspondence: sharifi.javad@mail.um.ac.ir

${ }^{1}$ Department of Geology, Faculty of Sciences, Ferdowsi University

of Mashhad, Mashhad, Iran

Full list of author information is available at the end of the article
}

more taxonomic investigations are needed to increase our knowledge on its paleogeographic occurrences and chronostratigraphic position.

The chronostratigraphic range of Eutrephoceras extends from the Upper Jurassic to the Miocene (Kummel, 1956; Landman et al., 2018). Most of the mid-Cretaceous occurrences of this taxon were recorded from European Albian and Cenomanian successions (AyoubHannaa et al., 2018; Jattiot et al., 2021; Kennedy et al., 2008; Machalski \& Wilmsen, 2015; Tajika et al., 2017; Wilmsen, 2000, 2016). The Koppeh Dagh Basin (northeastern Iran), in which the lower Albian to middle Cenomanian sedimentary rocks are exposed as Aitamir Formation, is known for its rich assemblage of diverse macro- and microfossils, but no nautilid fossils have been documented thus far. Most of the important taxonomic and biostratigraphic studies of this formation have 
focused on the ammonites (Seyed-Emami \& Aryai, 1981; Seyed-Emami et al., 1984; Immel et al. 1997; Mosavinia et al., 2007, 2014; Mosavinia, 2008; Mosavinia \& Wilmsen, 2011, 2017; Lehmann et al., 2019), and a few studies on planktonic foraminifera (Abdoshahi et al., 2010; Kalanat et al., 2016). We here describe and illustrate the first record of nautilids from the Albian-Cenomanian Aitamir Formation in the Koppeh Dagh Basin.

\section{Geological setting}

The Koppeh Dagh Mountains are located within the Alpine-Himalayan orogenic belt and were formed as a result of the collision of the Iran Plate with the southern margin of Eurasia, along the Palaeotethyan suture zone (Afshar-Harb, 1994; Alavi, 1991; Bretis et al., 2012; Wilmsen et al., 2009). Its sedimentary rocks consist of several kilometers of marine successions from the Jurassic up to the Miocene (e.g., Afshar-Harb, 1994). During the Albian and Cenomanian (Aitamir Formation), the Koppeh Dagh Basin was a passive margin siliciclastic shelf (Mosavinia \& Wilmsen, 2017). Regional tectonic activities strongly influenced local sedimentation processes and led to various characteristics such as fossil contents and thickness variations of the Aitamir Formation (Mosavinia \& Wilmsen, 2011, 2017; Robert et al., 2014). This time interval coincides with extensive volcanic activity in global scale which led to warm conditions, thereby enhancing marine productivity and leading to reduced carbonate contents (Arthur et al., 1985; Larson, 1991; Leckie et al., 2002). These extraordinary paleoecological conditions may have resulted in the presence of glauconitic and pyritized shales and sandstones in the Aitamir Formation.

The study area is located along the Khur anticline, SE of the Kalat-e-Naderi City, near the Taherabad Village (co-ordinates: N $36^{\circ} 37^{\prime} 05^{\prime \prime}$, E $60^{\circ} 04^{\prime}$ 03"). The outcrops in the studied area consist of several lithostratigraphic units from the Upper Jurassic (Mozduran Formation) to the Turonian (Abderaz Formation) as illustrated in Fig. 1. All described nautilid specimens were collected from the Aitamir Formation. The Aitamir Formation includes the lower Albian to middle Cenomanian at the Taherabad section and is composed of a 270-m-thick succession of shales, marls and bioturbated ridge-forming glauconitic and pyritized shales and sandstones. The Aitamir Formation lies conformably on the marls and dark shales of the Sanganeh Formation, and is overlain by the Abderaz

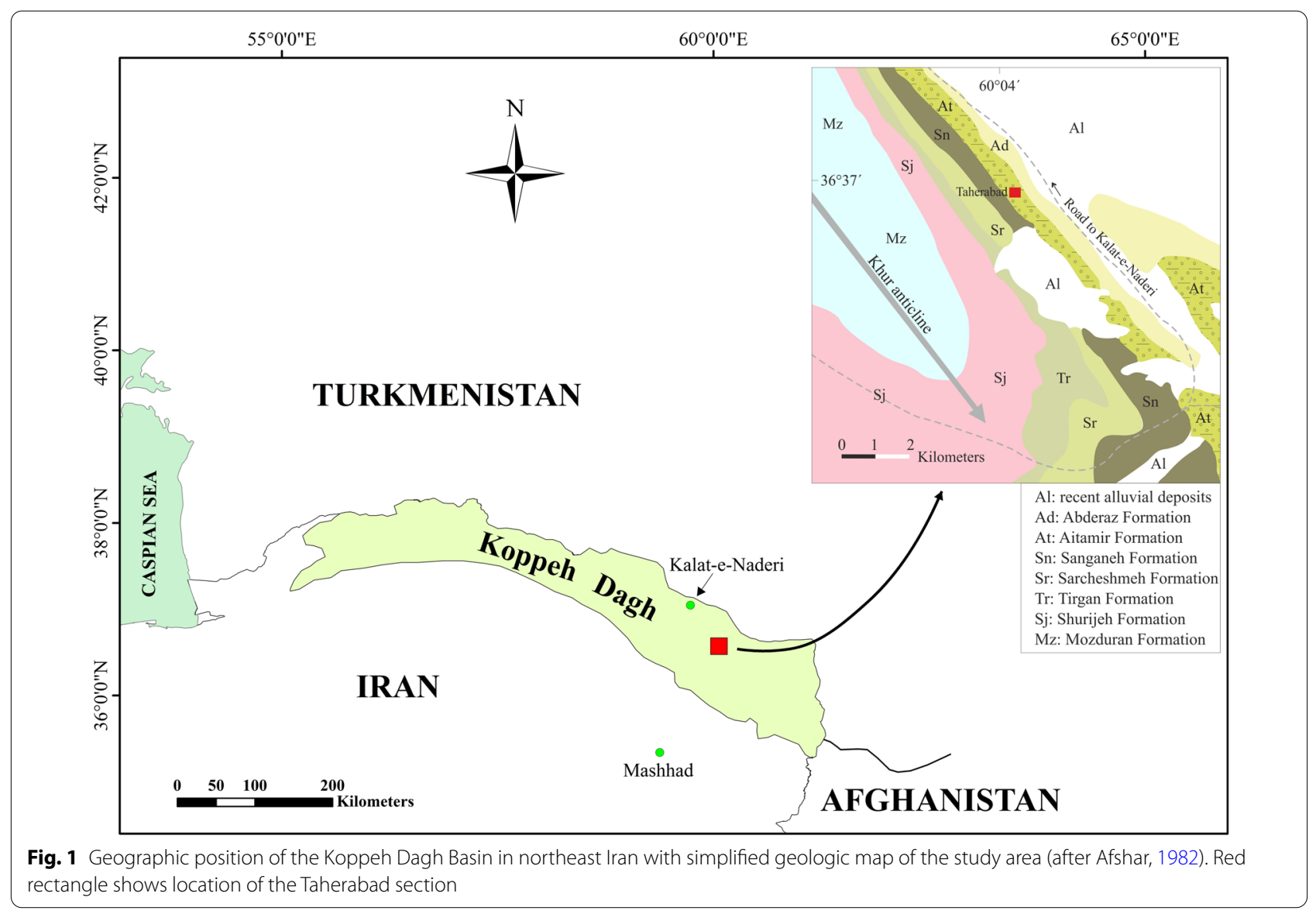




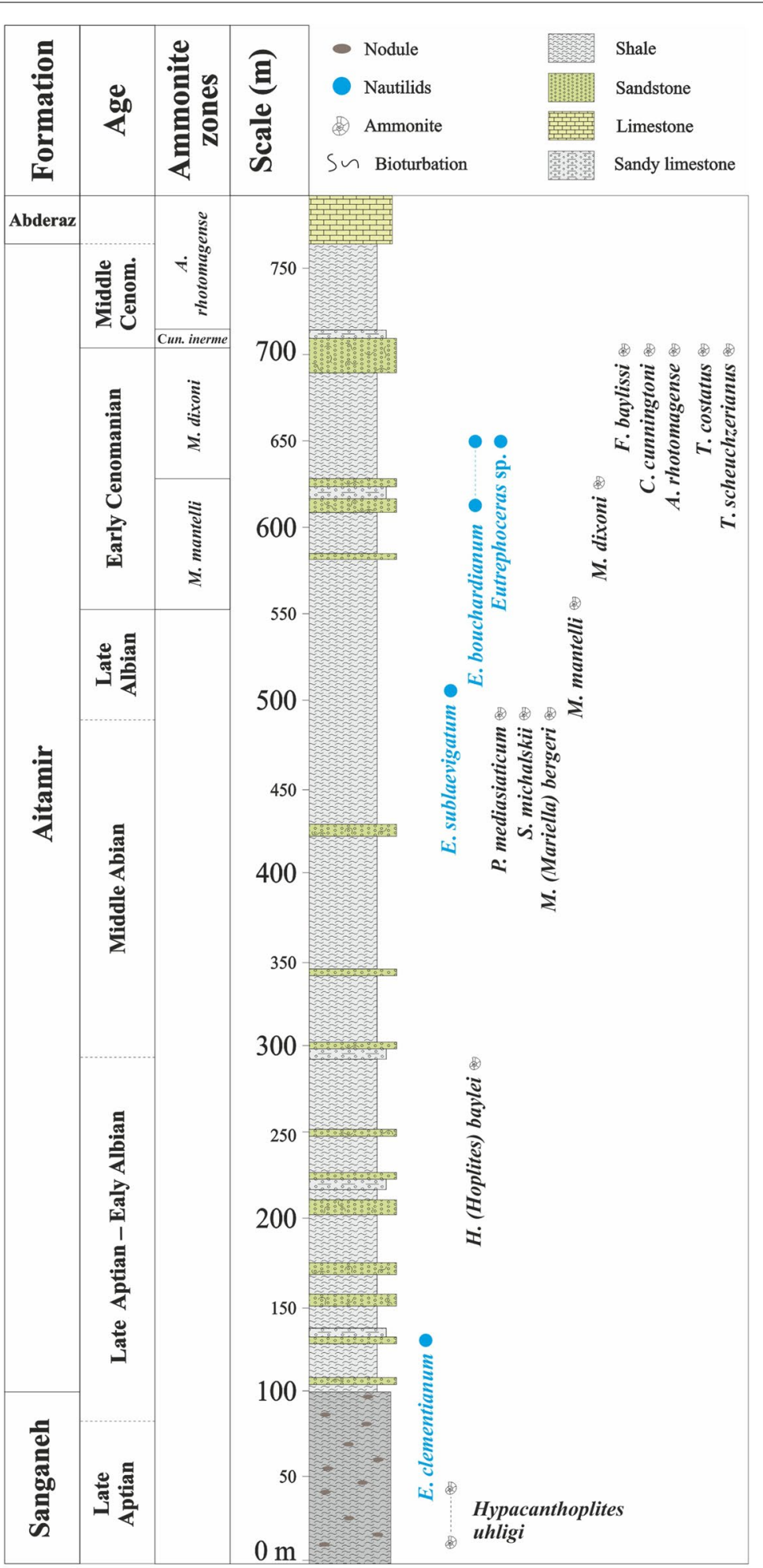

Fig. 2 Stratigraphic distribution of the nautilids in the Taherabad section. Ammonite zonation and substages boundaries are adopted from Mosavinia (2008); Mosavinia and Wilmsen (2011) and (2017); Mosavinia et al. (2014) and Lehmann et al. (2019). Abbreviations of ammonite genera: H.—Hoplites; M.—Mariella; P.—Placenticeras; S. —Semenoviceras; M.—Mantelliceras; T.—Turrilites; F.—Forbesiceras; C.—Cunningtoniceras; A.-Acanthoceras 
Formation, which is characterized by chalky limestones and marls. The Taherabad section is one of the wellstudied outcrops of the Aitamir Formation in the Koppeh Dagh Basin, and many previous authors have presented detailed lithostratigraphic description of the section (e.g., Kalanat et al., 2016; Mosavinia \& Wilmsen, 2017; Mosavinia et al., 2014).

\section{Materials and methods}

Five nautilid specimens were collected during 3 days of fieldwork. We took linear measurements of the conch parameters (diameter: dm; whorl width: ww, whorl height: wh) that were also used in Tajika et al. (2020). On the basis of the measurements above, we calculated the whorl expansion rate $\left[\left(\mathrm{dm}^{1} / \mathrm{dm}^{2}\right)^{*} 2\right.$ : WER $]$ and whorl width index $\left[\left(\mathrm{ww}^{1} / \mathrm{dm}^{1}\right)^{*} 2\right.$ : WWI $]$. We also documented the position of the siphuncle, the sutural morphology, and the number of septa per half whorl, wherever possible. Note that the small sample size does not allow for assessing the intraspecific variation, and thus we applied a typologic approach to discuss the taxonomy. As far as the higher taxonomic classification is concerned, we follow Teichert et al. (1964). All five illustrated specimens are housed in the Fossil Preparation Lab at the Department of Geology, Ferdowsi University of Mashhad, labeled with NAT repository codes (NAT-1 to NAT-5).

\section{Results and discussion}

All studied specimens belong to the genus Eutrephoceras, which is the first record of this genus in the Koppeh Dagh Basin, as well as in Iran. Even though the specimens are rather poorly preserved, we identified the following species (see systematic paleontology below): E. clementianum (d'Orbigny, 1840), E. sublaevigatum (d'Orbigny, 1850) and E. bouchardianum (d'Orbigny, 1840).

Previous studies documented several ammonite-rich beds and proposed the basic age framework for the Taherabad section of the Aitamir Formation and for adjacent areas (Lehmann et al., 2019; Mosavinia, 2008; Mosavinia \& Wilmsen, 2011, 2017; Mosavinia et al., 2014). We used the ammonite occurrences and zones to provide the age information for the stratigraphic levels in which we collected our specimens. Figure 2 shows the stratigraphic distribution of the collected nautilids accompanied by ammonite records, and the suggested substage boundaries. Albian ammonite biostratigraphic studies for the Taherabad section were carried out by Mosavinia et al.
(2014) and Lehmann et al. (2019), but no zonations were given for the interval in which we collected our specimens. Nevertheless, some of the reported ammonites helped us to constrain the substage boundaries within the Albian. By contrast, Cenomanian ammonites from the Taherabad section documented by Mosavinia and Wilmsen $(2011,2017)$ indicate a sequence of important bioevents that indicate a position in the Mantelliceras mantelli to Acanthoceras rhotomagense zones.

The base of the section lies $100 \mathrm{~m}$ below the Sanganeh/ Aitamir formation boundary, which is referred to as $0 \mathrm{~m}$. The nautilid occurrences in the Taherabad section begin with E. clementianum (NAT-1) at the second glauconitic sandstone bed of the Aitamir Formation (=129 m level). E. clementianum occurs between the latest Aptian index ammonite Hypacanthoplites uhligi (Fig. 3a-b) (at the $45 \mathrm{~m}$ level) and Hoplites (Hoplites) baylei (at the $290 \mathrm{~m}$ level), i.e., the middle to late Albian.

E. sublaevigatum (NAT-2) occurred at the $490 \mathrm{~m}$ level of the Taherabad section, just above the ammonite taxa Mariella (Mariella) bergeri (Fig. 3d-e), Semenoviceras michalskii (Fig. 3f-i) and Placenticeras mediasiaticum. S. michalskii and M. (M.) bergeri are the main classical components of the late Albian Dipoloceras cristatum and Stoliczkaia dispar zones. The upper part of the Taherabad section yielded two specimens of E. bouchardianum. At $612 \mathrm{~m}$, the first specimen (NAT-3) of this species was found within the M. mantelli Zone, indicating an early Cenomanian age. The highest recorded nautilids at Taherabad are E. bouchardianum (NAT-5) and Eutrephoceras sp. at the $660 \mathrm{~m}$ level. They fall within the Mantelliceras dixonii Zone. This zone is marked by the middle Albian Turrilites costatus (Fig. 3j), Turrilites scheuchzerianus, Forbesiceras baylissi, Cunningtoniceras cunningtoni and Acanthoceras rhotomagense (Fig. $3 \mathrm{k}-\mathrm{m}$ ) at the top, suggesting an early Cenomanian age for the stratigraphic interval between the $625 \mathrm{~m}-700 \mathrm{~m}$ levels.

\section{Systematic Paleontology}

Order Nautilida Agassiz, 1847

Superfamily Nautilaceae de Blainville, 1825

Family Nautilidae de Blainville, 1825

Genus Eutrephoceras Hyatt, 1894

(See figure on next page.)

Fig. 3 Selected age-diagnostic ammonite species from the Taherabad section, reported in previous studies. 1a-b, Hypacanthoplites uhligi

(Lehmann et al., 2019; Fig, 7.C). 2a-c, Mariella (Mariella) bergeri (Mosavinia et al., 2014; Fig. 8.C). 3a-d, Semenoviceras michalskii (Mosavinia et al., 2014; Fig. 5.B). 4, Turrilites costatus (Mosavinia \& Wilmsen, 2017; Fig. 5.F). 5a-c, Acanthoceras rhotomagense (Mosavinia \& Wilmsen, 2017; text-Fig. 5.B) 


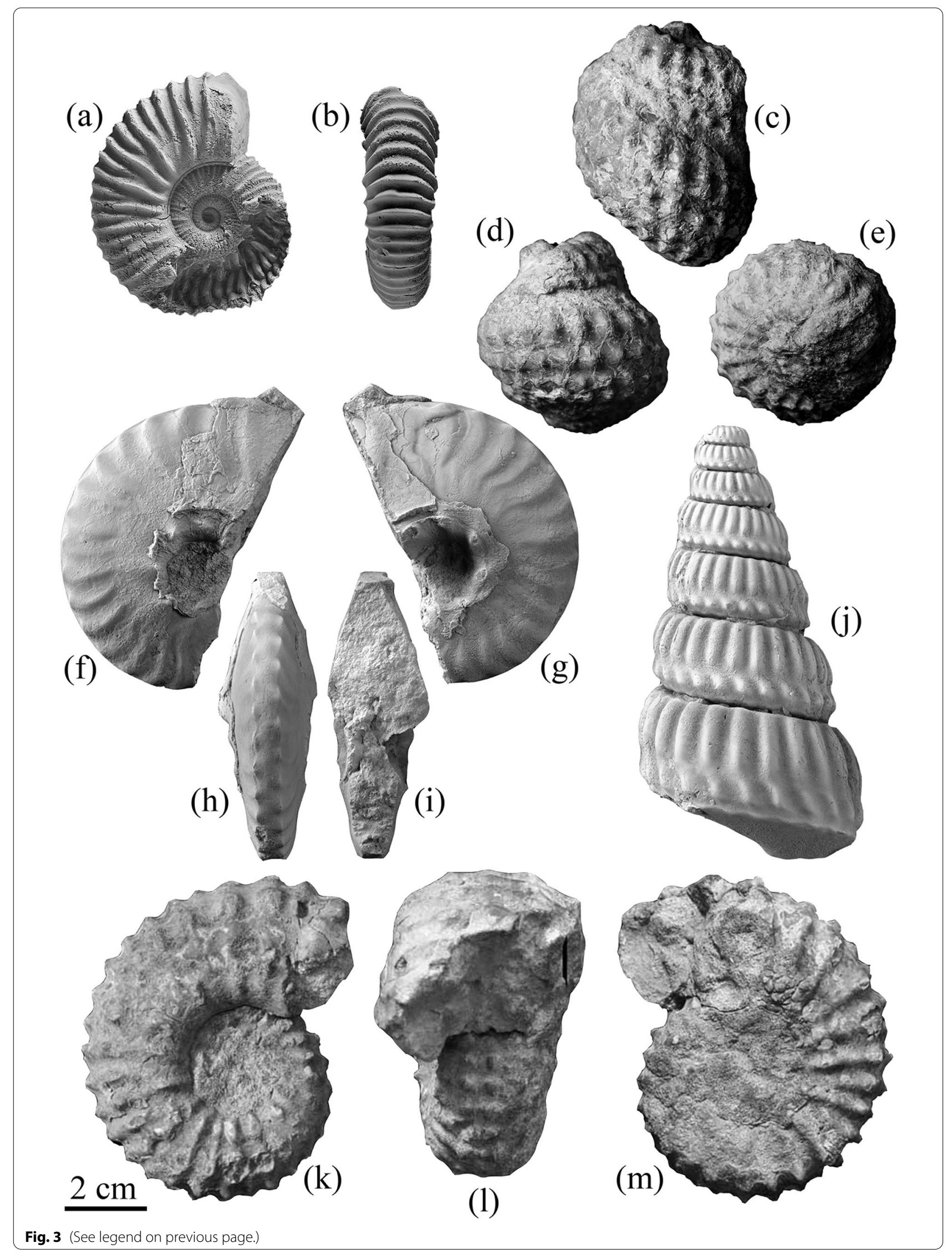


Eutrephoceras bouchardianum (d'Orbigny, 1840)

Figure 4

"1840 Nautilus bouchardianum d'Orbigny: 75, pl. 13, Figs. 1-3.

2015 Eutrephoceras bouchardianum (d'Orbigny, 1840); Machalski and Wilmsen; p. 497, text-Figs. 3A-D, 4A-B (with synonymy).

Material: Two specimens (NAT-3 and NAT-5 from the early Cenomanian).

Description: NAT-5 (Fig. 4d-g) measures $134 \mathrm{~mm}$ in conch diameter. The umbilicus is closed. The whorl section is very involute and depressed (WWI $=0.81-0.92$; Table 1). The whorl width is the greatest at the umbilicus. The venter is widely rounded. The shell is only partially preserved and smooth. The suture line is straight to slightly sinuous. There are nine suture lines in a half whorl. The position of the siphuncle was not observable. NAT-3 (Fig. 4a-c) measures $98 \mathrm{~mm}$ in conch diameter. The umbilicus appears nearly closed. The whorl section is widely rounded. This specimen is slightly less inflated than NAT-5 (WWI $=0.78-0.80$; Table 1 ). The suture line appears to be nearly straight, although it is only partially exposed. There are 11 septa per half whorl. The siphuncle is not visible.

Discussion: E. bouchardianum is characterized by its depressed whorl section (lectotype: $\mathrm{ww} / \mathrm{dm}=0.82$; Wiedmann, 1960), which we tentatively consider a diagnostic character of the species. E. sublaevigatum is similar, but has a less inflated whorl section (lectotype: $\mathrm{ww} / \mathrm{dm}=0.70$ Wiedmann, 1960). According to Wiedmann (1960), E. bouchardianum has a triangular whorl section, whereas E. sublaevigatum is rounded. However, the lectotype figured by Tintant and Gauthier (2006a) shows a somewhat widely rounded venter. Also, the hypotype of E. bouchardianum (Wiedmann, 1960, Table 19, Fig. I) exhibits a whorl section that looks similar to the lectotype of $E$. sublaevigatum. Thus, we cannot confirm that whorl section shape is a character that separates the two species. Wiedmann (1960) also mentioned that E. sublaevigatum differs from the present species in having a more peripherally located siphuncular position. However, this needs to be comprehensively reinvestigated. For example, Landman et al. (2018) and Tajika et al. (2020) found a significant change in the position of the siphuncle through ontogeny in Eutrephoceras dekayi from the lower Maastrichtian in Montana, USA, and Tajika and Klug (2020) also discovered a decreasing ontogenetic trend of siphuncular position in the post-hatching ontogeny of Nautilus. The lectotypes of some Albian-to-Cenomanian Eutrephoceras species, E. montmollini and E. bouchardianum are broken phragmocones, whereas E. sublaevigatum is a specimen with body chamber preserved. The ontogenetic changes of siphuncular position across/within species have not been investigated. The question arises whether the siphuncle position was always compared between the same growth stages or not. In addition to the above-mentioned characters, E. sublaevigatum is more evolute than E. bouchardianum according to Machalski and Wilmsen (2015), although we do not see such differences in the lectotypes of each species (i.e., both species seem to have a closed umbilicus). E. montmollini appears similar to $E$. bouchardianum in having an inflated whorl section (lectotype: $w w / d m=0.74$ ), but differs in having a wider umbilicus and a central siphuncle. Detailed examinations of the morphological changes occurring during the ontogeny of each species are urgently needed to improve Eutrephoceras taxonomy and phylogeny.

\section{Eutrephoceras clementianum (d'Orbigny, 1840) \\ Figure 5 \\ "1840 Nautilus Clementianus d'Orbigny: 77, pl. 13,} Figs. 1-6.

1960 Eutrephoceras clementianum (d'Orbigny) 1840; Wiedmann: pl. 168, pl. 18, Fig. J (with synonymy).

2006b Eutrephoceras clementianum (d'Orbigny, 1840); Tintant and Gauthier: pl. 2, Figs. 5a-b, 6).

2008 Eutrephoceras clementianum (d'Orbigny, 1840); Kennedy et al.; pl. 8, Figs. 8, 9.

2018 Eutrephoceras cf. clementianum (d'Orbigny, 1840); Ayoub-Hannaa et al.; Figs. 4A-E, 5A, B.

Material: One specimen (NAT-1 from the latest Aptian-early Albian).

Description: NAT-1 measures $254 \mathrm{~mm}$ in conch diameter with eroded body chamber preserved. The umbilicus is nearly closed. The whorl section is somewhat inflated (WWI $=0.58-0.75$ ) and trapezoidal/ rectangular. This specimen has the highest whorl expansion rate among the specimens documented in this paper (WER $=3.43$; Table 1 ). The suture line is slightly sinuous. Septal crowding in the last 13 septa indicates that it is a mature/submature specimen. There are 10 septa in a half whorl. The siphuncle is not visible.

Discussion: According to Wiedmann (1960), this species has a trapezoidal whorl section and is inflated (lectotype: WWI =0.72). Wiedmann (1960) also mentioned

(See figure on next page.)

Fig. 4 Eutrephoceras bouchardianum; a-c NAT-3, a apertural view, b and $\mathbf{c}$ lateral view. $\mathbf{d}-\mathbf{g}$, NAT-5, $\mathbf{d}$ apertural view, e ventral view, $\mathbf{f}$ and $\mathbf{g}$ lateral view 


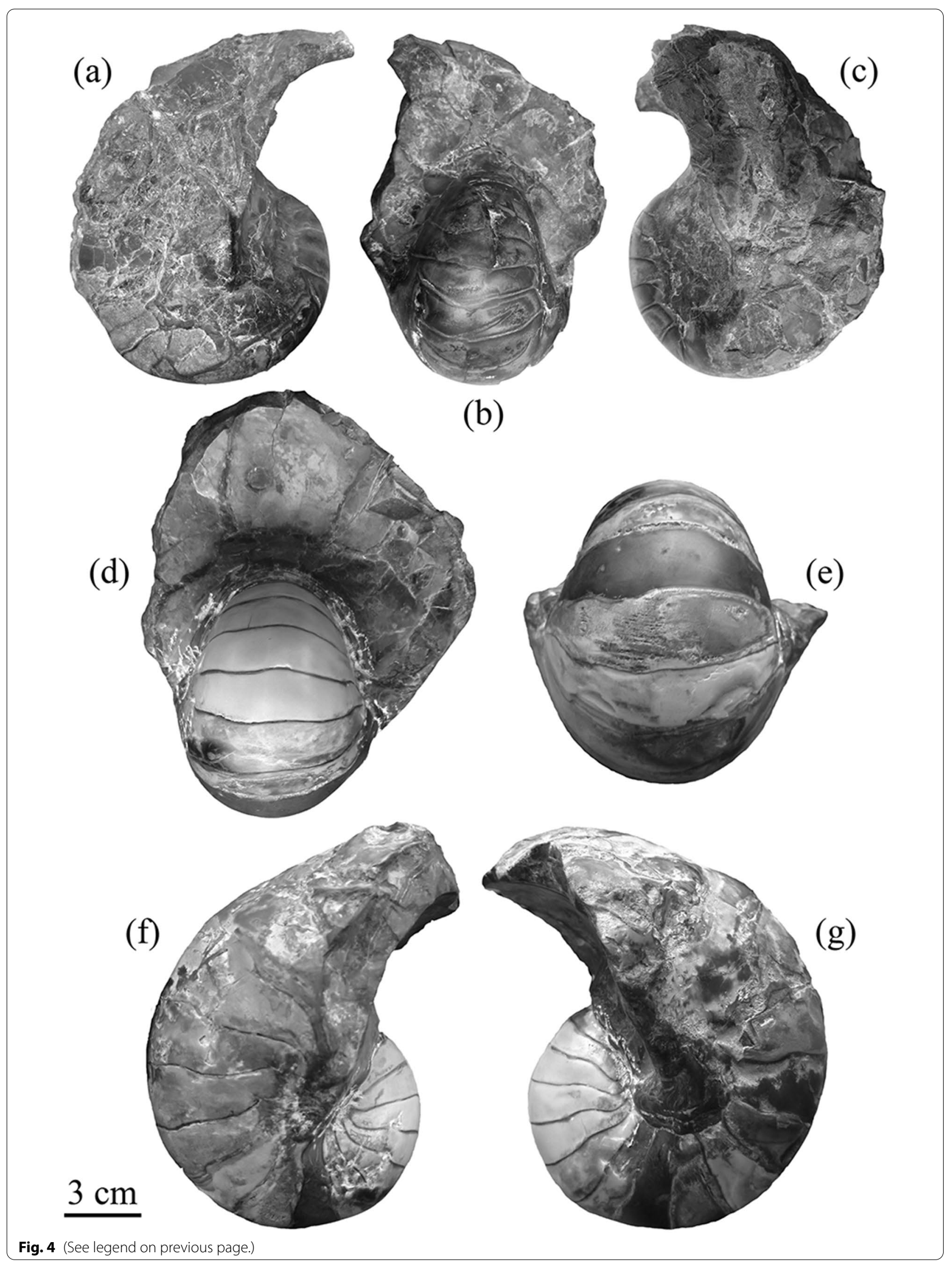


Table 1 Measurements ( $\mathrm{mm}$ ) of studied specimens

\begin{tabular}{|c|c|c|c|c|c|c|c|c|c|}
\hline Specimen & $\mathrm{dm}_{1}$ & $\mathrm{dm}_{2}$ & $w_{1}$ & $w_{w_{2}}$ & WER & $w_{1}$ & $w_{2}$ & $\mathrm{WWI}_{1}$ & $\mathrm{WWI}_{2}$ \\
\hline NAT-5 & 134 & 79 & 109 & 73 & 3.39 & 86 & 34 & 0.81 & 0.92 \\
\hline NAT-2 & 167 & 109 & 114 & 74 & 3.06 & 105 & 43 & 0.68 & 0.68 \\
\hline NAT-3 & 98 & 60 & 76 & 48 & 3.27 & 69 & 24 & 0.78 & 0.80 \\
\hline NAT-1 & 254 & 148 & 147 & 111 & 3.43 & 151 & 74 & 0.58 & 0.75 \\
\hline NAT-4 & & & 91 & & & & & & \\
\hline
\end{tabular}

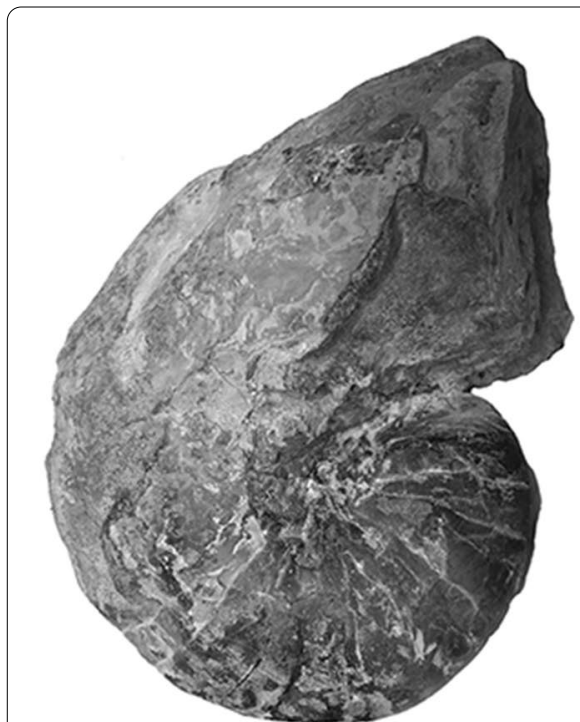

$4 \mathrm{~cm}$ (a)

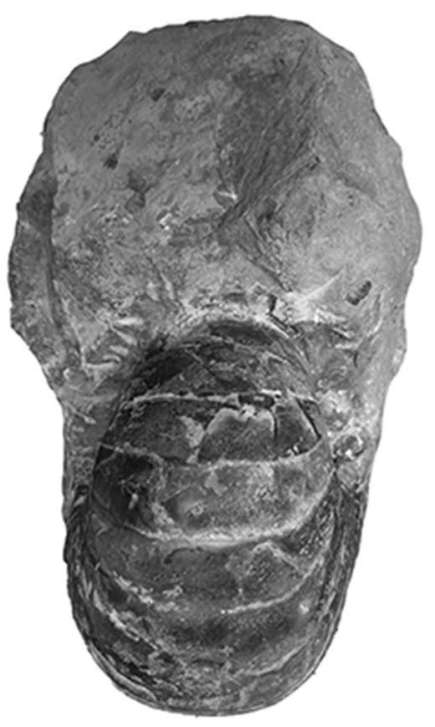

(b)

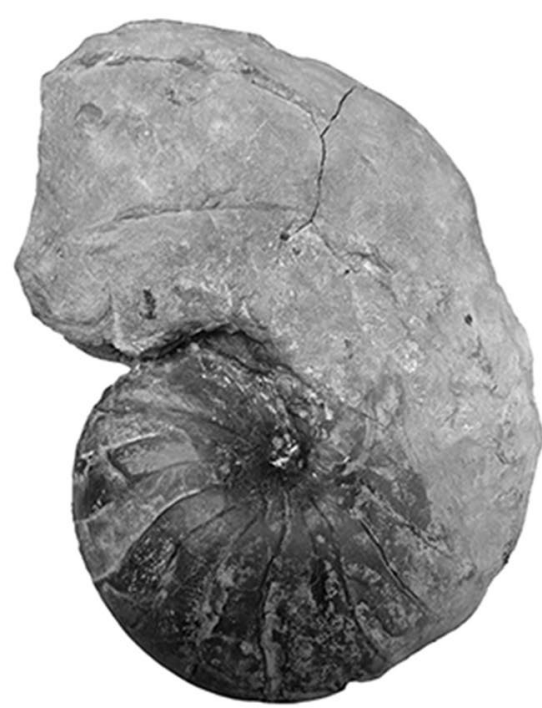

(c)

Fig. 5 Eutrephoceras clementianum; NAT-1, a apertural view, b and $\mathbf{c}$ lateral view

that the siphuncle is dorsally located in this species. However, the lectotype figured by Tintant and Gauthier (2006b; Fig. 5a, b) does not show the siphuncle position since the body chamber of the specimen covers the phragmocone. Presumably, the position of the siphuncle was assumed based on a poorly preserved syntype (a single chamber; Tintant \& Gauthier, 2006b; pl 2, Fig. 6). Also, the siphuncular position shifts towards the dorsal margin in at least some taxa (Tajika et al., 2020). The above-mentioned chamber was likely formed slightly before the sexual maturity based on the size. These suggest that the dorsal location of siphuncle may be the result of its ontogenetic change. It is also worth mentioning that our specimen is much larger $(254 \mathrm{~mm})$ than the lectotype $(180 \mathrm{~mm})$. Assuming that the lectotype is an adult specimen, it is possible that Eutrephoceras in Koppeh Dagh Basin grew and reached a much larger adult size than the one in France. In modern Nautilus, it is known that different geographic populations exhibit different adult sizes (Saunders, 1987; Tajika et al., 2018).
Our discovery may imply that different geographic populations in fossil nautilids have a similar trend.

\section{Eutrephoceras sublaevigatum (d'Orbigny, 1850)}

Figure 6

*1850 Nautilus Sublaevigatus d'Orbigny: Prodrome II, S. 189.

1960 Eutrephoceras sublaevigatum (d'Orbigny) 1960; Wiedmann; p. 165, pl. 19, fig. O, pl. 20, fig. A, pl. 23, fig. L. (with synonymy).

2006c Eutrephoceras sublaevigatum (d'Orbigny, 1840); Tintant and Gauthier: pl. 4, fig, 3a, b; pl. 5, Fig. 1a, b, $2 \mathrm{a}-\mathrm{c}$.

2017 Eutrephoceras sublaevigatum (d'Orbigny, 1850); Tajika et al.; Fig. 5C, C, K, L.

2021 Eutrephoceras sublaevigatum (d'Orbigny, 1850); Jattiot et al.; Fig. 27D-P.

Material: One specimen (NAT-2 from the late Albian).

Description: NAT-2 measures $167 \mathrm{~mm}$ in conch diameter. The umbilicus is barely visible but appears nearly 


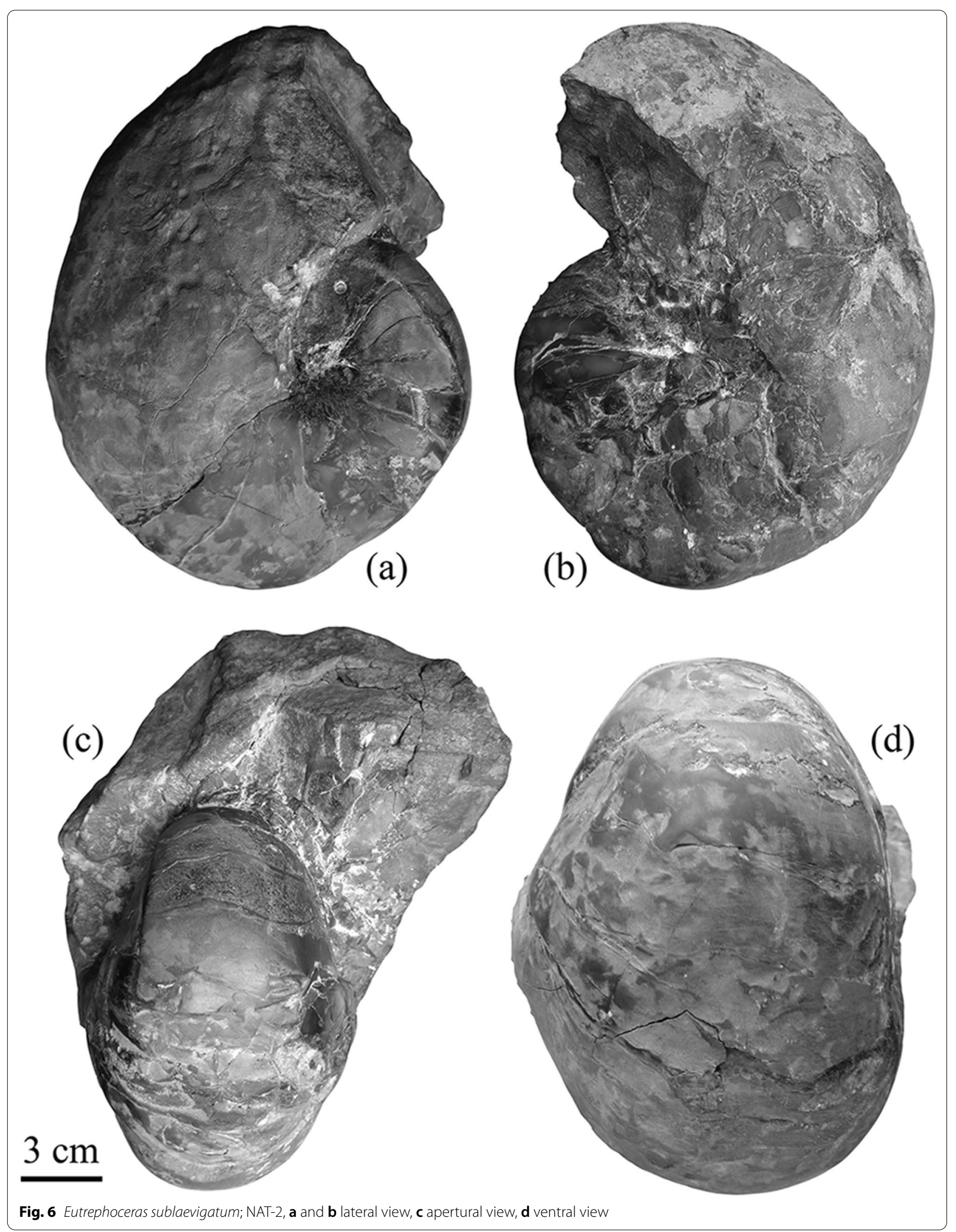



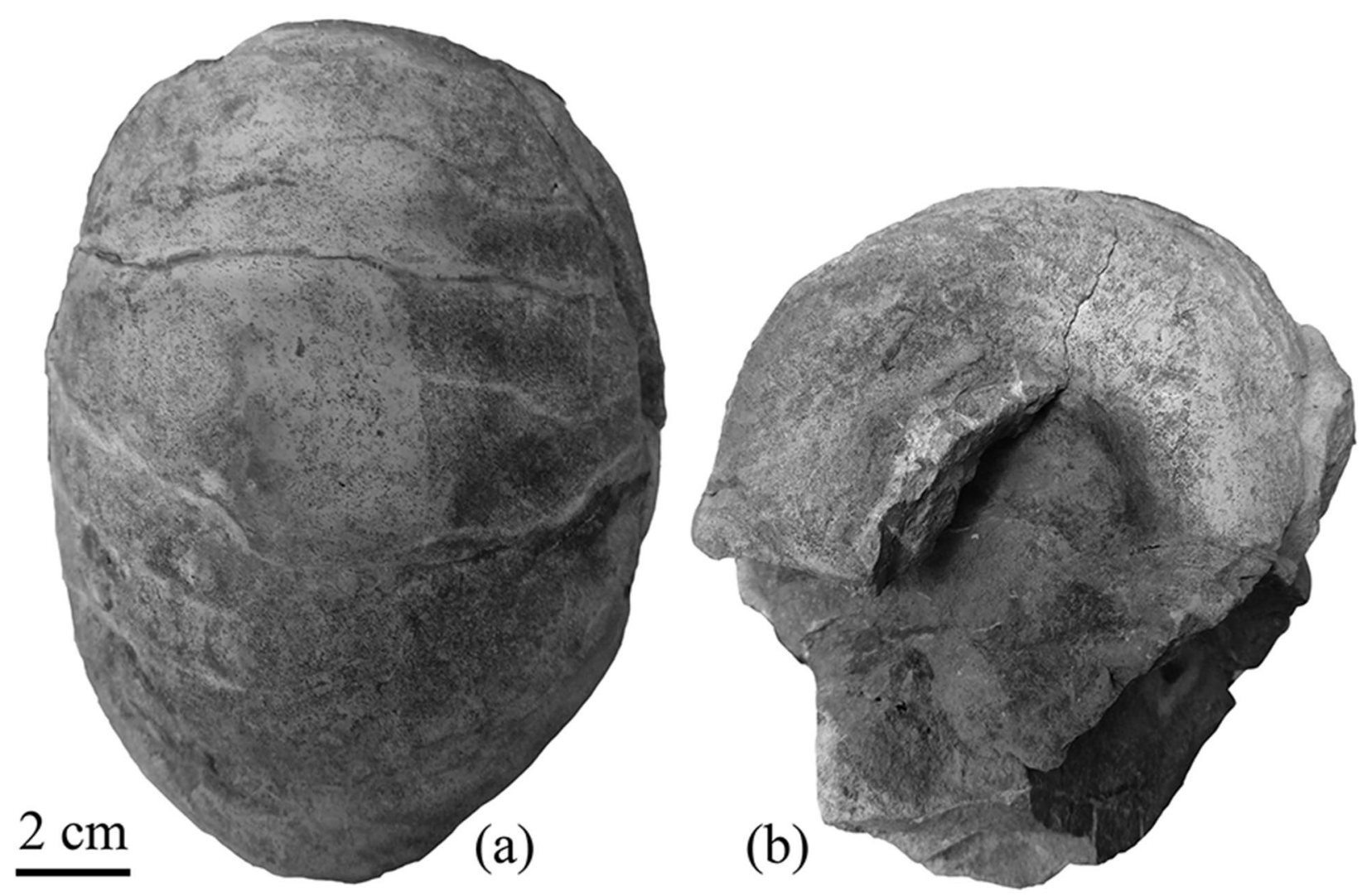

Fig. 7 Eutrephoceras sp.; NAT-4, a ventral view, b apertural view

closed. The whorl section is inflated (WWI $=0.68$ ) and rather narrowly rounded. This specimen bears the smallest whorl expansion rate (WER $=3.06$; Table 1 ) among the documented specimens. The suture is slightly sinuous. There are 13 septa in a half whorl.

Discussion: As discussed above, E. sublaevigatum appears similar to E. bouchardianum but differs in whorl width index (see the discussion for E. bouchardianum). As in E. clementianum discussed above, our specimen of E. sublaevigatum is larger $(167 \mathrm{~mm})$ than the lectotype $(110 \mathrm{~mm})$. Provided that the lectotype is an adult specimen, our specimen has a larger adult size, which is congruent with our hypothesis that Eutrephoceras attained a larger adult size in Koppeh Dagh Basin.

\section{Eutrephoceras sp.}

Figure 7

Material: One incomplete specimen (NAT-4 from the early Cenomanian).

Description: NAT-4 is an incomplete broken phragmocone that measures $91 \mathrm{~mm}$ in whorl width. The whorl section is broadly rounded. The suture line is slightly sinuous.
Discussion: The specimen is assigned to Eutrephoceras based on the suture line and broadly rounded whorl section. However, the preservation does not allow for species identification.

\section{Conclusions}

Five nautilid specimens were collected from the Albianto-Cenomanian succession of the Taherabad section, situated in the Koppeh Dagh Basin. Lithologically, Taherabad section is composed of a 270-m-thick succession of shales, marls and intercalated ridge-forming sandstones. All the recorded nautilids in the section belong to the genus Eutrephoceras and comprise three taxa identified at species level, Eutrephoceras clementianum (d'Orbigny, 1840), E. sublaevigatum (d'Orbigny, 1850), E. bouchardianum (d'Orbigny, 1840) and one specimen at genus rank, Eutrephoceras sp. All of them are systematically described and recorded from Iran for the first time. Also, several ammonite bioevents in the Taherabad section provided a basis for the detailed biostratigraphic subdivision and constrained the age of the studied nautilids. E. clementianum occurs above the latest Aptian index ammonite Hypacanthoplites uhligi; E. sublaevigatum came from the late Albian beds and 
two specimens of E. bouchardianum with Eutrephoceras sp. are from the early Cenomanian M. mantelli and $M$. dixonii zones.

\section{Acknowledgements}

Our sincere thanks go to Markus Wilmsen (Dresden) and an anonymous reviewer for their constructively reviewing the manuscript. Christopher Whalen (American Museum of Natural History) is thanked for proofreading an earlier version of the manuscript.

\section{Authors' contributions}

JS, AM and MHTA conceived and planned the idea of this study. They carried out the fieldwork, mechanical cleaning of the nautilids and contributed in interpreting of the stratigraphic position of the recovered nautilids. JS and AT performed the morphologic measurements of the specimens. AT wrote the systematic description of the specimens. JS designed the figures. All authors read and approved the final manuscript.

\section{Funding}

This study received no grant from any funding agency in the academic, public, commercial, or not-for-profit sectors.

\section{Availability of data and materials}

All specimens illustrated and described herein are stored at the Fossil Preparation Lab at the Department of Geology, Ferdowsi University of Mashhad, Mashhad, Iran.

\section{Declarations}

\section{Competing interests}

All authors declare that there are no competing interests.

\section{Author details}

'Department of Geology, Faculty of Sciences, Ferdowsi University of Mashhad, Mashhad, Iran. ${ }^{2}$ Division of Paleontology (Invertebrates), American Museum of Natural History, New York, USA. ${ }^{3}$ University Museum, University of Tokyo, Tokyo, Japan.

Received: 10 February 2021 Accepted: 14 June 2021

Published online: 21 July 2021

\section{References}

Abdoshahi, M., Vahidinia, M., Ashuri, A., \& Rahimi, B. (2010). Microbiostratigraphy of Cenomanian-Turonian boundary in the Shurab section, east of Koppeh-Dagh basin [in Farsi]. Sedimentary Facies, 1, 61-70.

Afshar, A. (1982). Geological map of Sarakhs. National Iranian Oil Company, scale 1/250,000, 1 sheet. No. L4.

Afshar-Harb, A. (1994). The geology of the Koppeh Dagh, Iran (p. 265). Geological Survey of Iran.

Alavi, M. (1991). Sedimentary and structural characteristics of the Paleo-Tethys remnants in northeastern Iran. Geological Society of America Bulletin, 103, 983-992.

Agassiz, L. (1847). An introduction to the study of natural history, in a series of lectures delivered in the hall of the College of Physicians and Surgeons (p. 58). Greeley \& McGrath, New York.

Arthur, M.A., Dean, W.E., \& Schlanger, S.O. (1985). Variations in the global carbon cycle during the Cretaceous related to climate, volcanism, and changes in atmospheric $\mathrm{CO}_{2}$. In: Sundquist, E.T., Broecker, W.S. (eds.), The Carbon Cycle and Atmospheric $\mathrm{CO}_{2}$ : Natural Variations Archean to Present. American geophysical union, Geophysical Monograph Series, 32, 504-529.

Ayoub-Hannaa, W., Radulović, B. V., Fürsich, F. T., Vasić, N. D., \& Radulović, V. J. (2018). Late Albian ammonites from Koraćica (Kosmaj Mountain, central Serbia) and their biostratigraphic implications. Cretaceous Research, 85, 280-308.

Blainville, H.M.D. (1825-27). Manuel de malacologie et de conchyliologie. (p. 664). Paris and Strasbourg (Levrault).

Bretis, B., Grasemann, B., \& Conradi, F. (2012). An active fault zone in the western Kopet Dagh (Iran). Austrian Journal of Earth Sciences, 105, 95-107.
Hyatt, A. (1894). Phylogeny of an acquired characteristic. Proceedings of the American Philosophical Society, 32, 349-647.

Immel, H., Seyed-Emami, K., \& Afshar-Harb,. (1997). Kreide-Ammoniten aus dem iranischen Teil des Koppeh-Dagh (NE-Iran). Zitteliana, 21, 159-190.

Jattiot, R., Lehmann, J., Latutrie, B., Vuarin, P., Tajika, A., \&Vennin, E. (2021). Reappraisal of the latest Albian (Mortoniceras fallax Zone) cephalopod fauna from the classical Salazac locality (Gard, southeastern France). Geobios, 64, 1-46.

Kalanat, B., Vahidinia, M., Vaziri-Moghaddam, H., \& Mahmudy-Gharaie, M. H. (2016). Planktonic foraminiferal turnover across the Cenomanian-Turonian boundary (OAE2) in northeast of Tethys realm, Koppeh-Dagh basin. Geologica Carpathica, 67, 451-462.

Kennedy, W. J., Jagt, J. W. M., Amédro, F., \& Robaszynski, F. (2008). The late Late Albian (Mortoniceras fallax Zone) cephalopod fauna from the Bracquegnies formation at Strépy-Thieu (Hainaut, southern Belgium). Geologica Belgica, 11, 35-69.

Kröger, B., Vinther, J., \& Fuchs, D. (2011). Cephalopod origin and evolution: a congruent picture emerging from fossils, development and molecules. BioEssays, 33, 602-613.

Kummel, B. (1956). Post-Triassic Nautiloid genera. Bulletin of the Museum of Comparative Zoology at Harvard College in Cambridge, 114, 319-494.

Landman, N. H., Goolaerts, S., Jagt, J. W., Jagt-Yazykova, E. A., Machalski, M., \& Yacobucci, M. M. (2014). Ammonite extinction and nautilid survival at the end of the Cretaceous. Geology, 42(8), 707-710.

Landman, N. H., Grier, J. W., Cochran, J. K., Grier, J. C., Petersen, J. G., \& Towbin, W. H. (2018). Nautilid nurseries: hatchlings and juveniles of Eutrephoceras dekayi from the lower Maastrichtian (Upper Cretaceous) Pierre Shale of east-central Montana. Lethaia, 51, 48-74.

Larson, R. L. (1991). Geological consequences of super plumes. Geology, 19, 963-966.

Leckie, R. M., Bralower, T. J., \& Cashman, R. (2002). Oceanic anoxic events and plankton evolution: biotic response to tectonic forcing during the midCretaceous. Paleoceanography, 17, 13-1-13-29.

Lehmann, J., Mosavinia, A., \& Wilmsen, M. (2019). Parahoplitid ammonites and narrowing down the Aptian/Albian boundary interval in northern Iran. Cretaceous Research, 94, 207-228.

Machalski, M., \& Wilmsen, M. (2015). Taxonomy and taphonomy of Cenomanian (Upper Cretaceous) nautilids from Annopol, Poland. Acta Geologica Polonica, 65(4), 495-506.

Mosavinia, A. (2008). Biostratigraphy of the middle Cretaceous in the eastern Koppeh Dagh, NE Iran (based on the ammonite fauna) [in Farsi] (p. 350). Payame Noor University.

Mosavinia, A., \& Wilmsen, M. (2011). Cenomanian Acanthoceratoidea (Cretaceous Ammonoidea) from the Koppeh Dagh, NE Iran: taxonomy and stratigraphic implications. Acta Geologica Polonica, 61, 175-192.

Mosavinia, A., \& Wilmsen, M. (2017). Cenomanian Turrilitidae (Cretaceous heteromorphy ammonites) from the Koppeh Dagh, northeast Iran: taxonomy and stratigraphic implications. Cretaceous Research, 78, 113-126.

Mosavinia, A., Lehmann, J., \& Wilmsen, M. (2014). Late Albian ammonites from the Aitamir Formation (Koppeh Dagh, northeast Iran). Cretaceous Research, 50, 72-88.

Mosavinia, A., Wilmsen, M., Aryai, A. A., Chahida, M. R., \& Lehmann, J. (2007) Mortoniceratinae (Ammonitina) from the Upper Albian (Cretaceous) of the Atamir Formation, Koppeh Dagh Mountains, NE Iran. Neues Jahrbuch Für Geologie Und Paläontologie, 246, 83-95.

Orbigny, A. d.' (1840-1842). Paléontologie Française. Terrains crétacés I, Céphalopodes. Masson, Paris, 662 pp. (1-120: 1840; 121-430: 1841; 431-662: 1842).

Orbigny, A. d. .' (1850). Prodrome de paléontologie stratigraphique universelle des animaux mollusques et rayonnés faisant suite au cours élémentaire de paléontologie et de Géologie stratigraphiques. Masson, Paris, Tome, 2, 1-427.

Robert, A. M. M., Letouzey, J., Kavoosi, M. A., Sherkati, S., Müller, C., Vergés, J., \& Aghababaei, A. (2014). Structural evolution of the Kopeh Dagh fold-andthrust belt (NE Iran) and interactions with the South Caspian Sea Basin and AmuDarya Basin. Marine and Petroleum Geology, 57, 68-87.

Saunders, W. B. (1987). The species of Nautilus. In W. B. Saunders \& N. H. Landman (Eds.), Nautilus (pp. 35-52). Springer.

Seyed-Emami, K., \& Aryai, A. A. (1981). Ammoniten aus dem unteren Cenoman von Nordostiran (Koppeh-Dagh). Mitteilungen Der Bayerischen Staatssammlung Für Paläontologie Und Historische Geologie, 21, 23-39.

Seyed-Emami, K., Förster, R., \& Mojtehedi, A. (1984). Ammoniten aus dem mittleren Cenoman von Nordostiran (Koppeh-Dagh). Neues Jahrbuch Für Geologie Und Paläontologie, 3, 159-172. 
Tajika, A., \& Klug, C. (2020). How many ontogenetic points are needed to accurately describe the ontogeny of a cephalopod conch? A case study of the modern nautilid Nautilus pompilius. PeerJ, 8, e8849.

Tajika, A., Kürsteiner, P., Pictet, A., Lehmann, J., Tschanz, K., Jattiot, R., \& Klug, C. (2017). Cephalopod associations and palaeoecology of the Cretaceous (Barremian-Cenomanian) succession of the Alpstein, northeastern Switzerland. Cretaceous Research, 70, 15-54.

Tajika, A., Landman, N. H., Morimoto, N., Ikuno, K., \& Linn, T. (2020). Patterns of intraspecific variation through ontogeny: a case study of the Cretaceous nautilid Eutrephoceras dekayi and modern Nautilus pompilius. Palaeontology, 63, 807-820.

Tajika, A., Morimoto, N., Wani, R., \& Klug, C. (2018). Intraspecific variation in cephalopod conchs changes during ontogeny: perspectives from three-dimensional morphometry of Nautilus pompilius. Paleobiology, 44, 118-130.

Teichert, K. (1964). Morphology of hard parts. In: Moore, R.C. (Ed.), Treatise o Invertebrate Paleontology, Part K, Mollusca 3, K13-K53. Geological Society and University of Kansas Press.

Tintant, H. \& Gauthier, H. (2006a). Eutrephoceras bouchardianum (d'Orbigny, 1840). In: Gauthier, H. (Ed.), Révision critique de la Paléontologie Française d'Alcide d'Orbigny. Volume IV, Céphalopodes Crétacés: p. 20. Backhys; Leiden.

Tintant, H. \& Gauthier, H. (2006b). Eutrephoceras clementinum (d'Orbigny, 1840). In: Gauthier, H. (Ed.), Révision critique de la Paléontologie Française d'Alcide d'Orbigny. Volume IV, Céphalopodes Crétacés: p. 20-21. Backhys; Leiden.

Tintant, H. \& Gauthier, H. (2006c). Eutrephoceras sublaevigatum (d'Orbigny, 1840). In: Gauthier, H. (Ed.), Révision critique de la Paléontologie Française
d'Alcide d'Orbigny. Volume IV, Céphalopodes Crétacés: p. 22. Backhys; Leiden.

Wiedmann, J. (1960). Zur Stammesgeschichte jungmesozoischer Nautiliden unter besonderer Berücksichtigung der iberischen Nautilinae D'ORB. Palaeontographica Abteilung, 115, 144-206.

Wilmsen, M. (2000). Late Cretaceous nautilids from northern Cantabria, Spain. Acta Geologica Polonica, 50, 29-43.

Wilmsen, M. (2016). Nautiliden. In: Niebuhr, B. \&Wilmsen, M. (Eds), KreideFossilien in Sachsen, Teil 2. Geologica Saxonica, 62, 59-102.

Wilmsen, M., \& Mosavinia, A. (2011). Phenotypic plasticity and taxonomy of Schloenbachia varians (J. Sowerby, 1817). Paläontologische Zeitschrift, 85, 169-184.

Wilmsen, M., Fürsich, F. T., Seyed-Emami, K., Majidifard, M. R., \&Taheri, J. (2009). The Cimmerian orogeny in northern Iran: tectono-stratigraphic evidence from the foreland. Terra Nova, 21, 211-218.

\section{Publisher's Note}

Springer Nature remains neutral with regard to jurisdictional claims in published maps and institutional affiliations.

\section{Submit your manuscript to a SpringerOpen ${ }^{\circ}$ journal and benefit from:}

- Convenient online submission

- Rigorous peer review

- Open access: articles freely available online

- High visibility within the field

- Retaining the copyright to your article

Submit your next manuscript at $\boldsymbol{\nabla}$ springeropen.com 